\title{
EU:n maatalouspolitiikka ja kestävä kehitys
}

\author{
Tuomas Kuhmonen, Hanna Partio \& Irene Kuhmonen
}

\begin{abstract}
Abstrakti
Maatalous on EU:n pisimmälle integroitu toimiala ja politiikanala. Yhteisen maatalouspolitiikan tarina 1960-luvulta nykyaikaan kuvaa muuttuvia ja monipuolistuvia yhteiskunnallisia haasteita, joihin politiikkatoimenpiteillä on vastattu. Alkuaikoina päähuomio oli elintarvikehuollossa ja viljelijöiden toimeentulossa, mutta ajan myötä mukaan on tullut vahvoja alueellisia, ympäristöllisiä ja myös kulttuurisia painotuksia. Kestävän kehityksen käsittein tarkasteltuna yhteinen maatalouspolitiikka on muuttunut moniulotteisemmaksi. Viimeisimmillä uudistuksilla on tavoiteltu kestävyyden sekä taloudelliseen, ympäristölliseen, sosiaaliseen että kulttuuriseen ulottuvuuteen liittyviä muutoksia. Kestävä kehitys ei ole ollut eksplisiittisesti uudistusten perusta, mutta lukuisilla maatalouspolitiikan omilla käsitteillä on kuvattu ja tavoiteltu kestävän kehityksen ideaalia. Kestävän kehityksen viitekehys voi olla hyödyllinen ratkaistaessa yhteiskunnassa kulloinkin ongelmallisina pidettyjä maatalouteen ja ruokahuoltoon liittyviä kysymyksiä, koska se ohjaa systemaattisesti asettamaan esimerkiksi tavoitteet, arvioimaan käytettäviä keinoja ja ennakoimaan vaikutuksia yhtä aikaa sekä taloudellisen, ympäristöllisen, sosiaalisen että kulttuurisen ulottuvuuden osalta.
\end{abstract}

Avainsanat: Euroopan unioni; kestävä kehitys; yhteinen maatalouspolitiikka

\section{Tausta ja tavoitteet}

Maatalouspolitiikka on maatalouselinkeinoon kohdistuvaa julkista politiikkaa, jonka avulla yhteiskunta pyrkii saavuttamaan sellaisia tavoitteita, joita vapaat markkinat eivät tuota. Yhteiskunta ohjaa maatalouselinkeinoa ja elintarviketuotantoa yleensä verotuksen, tulonsiirtojen (tukien), ulkomaankaupan ja erilaisten normien kautta (Stiglitz 1987). Maatalouspolitiikalla pyritään vaikuttamaan ennen kaikkea tuotannon määrään ja 
tuotantotapoihin, viljelijöiden tulokehitykseen ja elinkeinon rakennekehitykseen. Maatalouspolitiikan luonteella on tunnistettavissa oleva kehitysura. Yhteiskunnan kehityksen varhaisessa vaiheessa maatalouselinkeino on laaja, eikä se kohtaa juuri kilpailua toimeentulolähteenä. Vahvistuvan valtion ja kansalaisten hyvinvoinnin turvaaminen vaatii verotuloja, joita saadaan verottamalla maataloustuotantoa ja -vientiä. Kun muiden toimialojen tulotaso nousee maataloutta nopeammin, tämän elintärkeän toimialan viennin verottamisesta yleensä luovutaan ja sitä aletaan sen sijaan tukea rajasuojalla ja tulonsiirroilla (Anderson \& Hayami 1986; Barrett ym. 2010; de Gorter \& Swinnen 2002; OECD 2013; Swinnen 2010). Tämä tarina on toistunut historian saatossa kymmenissä maissa ja toistuu parhaillaan monissa kehittyvissä talouksissa. Valtioiden halu puuttua maatalouselinkeinon ja elintarvikemarkkinoiden toimintaan on siis pitkäkestoinen ja maailmanlaajuinen ilmiö. Sen perusteet, muodot ja kohdentuminen ovat kuitenkin muuttuneet voimakkaasti ajan saatossa.

Euroopan unionin (EU) yhteinen maatalouspolitiikka syntyi kehityskaaren siinä kohdassa, jossa oli jo siirrytty maatalouden verottamisesta sen tukemiseen. Yhteinen maatalouspolitiikka on EU:n vanhin ja pisimmälle integroitu politiikanala. Maatalouspolitiikan tavoitteet määriteltiin vuoden 1957 Rooman sopimuksessa. Sodanjälkeistä jälleenrakennuskautta elävässä läntisessä Euroopassa ne liittyivät vahvasti elintarvikehuoltoon, ruuan tuotanto- ja kulutusmahdollisuuksiin (Tracy 1989). Talouskasvun vahvistama kysyntä, suojatut kotimarkkinat ja teknologisen kehityksen parantama tuottavuus turvasivat toki elintarvikehuollon, mutta johtivat jo 1980-luvulla vaikeisiin ylituotanto-ongelmiin. Maataloustuotanto kasvoi nopeasti kaikkialla, mutta erityisesti parhailla viljelysalueilla, joilla alkoi ilmetä vakavia ympäristöongelmia. Vuoristoseudut perinnemaisemineen ja -viljelyksineen taas uhkasivat autioitua. Kansainvälisen kaupan vapauttamista koskevat neuvottelut (GATT/WTO), maatalousbudjetin kasvu, rakenneongelmaisten alueiden lisääntyminen EU:n laajentumisen myötä ja ympäristötietoisuuden kasvu vaikuttivat osaltaan siihen, että 1990-luvulla käynnistyi kokonainen politiikkauudistusten sarja (vuosina 1992, 1999, 2003, 2008 ja 2013). Näiden uudistusten ydinsisältö on liittynyt maatalouden ympäristövaikutuksiin, maaseutualueisiin (ml. kulttuuriarvot), sosiaalisiin näkökulmiin ja kansainvälisiin velvoitteisiin. Tuontisuojaa on 
purettu ja markkinoiden tasapainottamisesta säästyneet varat on ohjattu viljelijöiden toimeentulon turvaamiseen erilaisilla kohdennetuilla tuilla.

EU:n yhteisen maatalouspolitiikan kehityspolku on myös tarina kestävän kehityksen ideaalin tai tavoitetilan asettumisesta politiikan viitekehykseksi. Ajatus kestävästä kehityksestä vaikutti käytännössä kaikkiin 1990-luvulta alkaneisiin politiikkauudistuksiin, vaikka asioita kuvattiin pääasiassa maatalouspolitiikan omilla (monimutkaisilla) käsitteillä. Yhteisen politiikan alkuaikoina koko kestävän kehityksen käsitettä nykyisessä muodossaan ei vielä ollut edes olemassa. Julkinen keskustelu maataloudesta on usein polarisoitunutta. Sen perusteella tuntuu vaikealta sovittaa yhteen esimerkiksi maatalouden aiheuttamat ympäristöongelmat, viljelijöiden heikko toimeentulo, maaseudun heikentyvä elinvoimaisuus, suuri maataloustuki ja ruuan korkea hinta. Kestävän kehityksen käsite pyrkii kuitenkin nimenomaan nivomaan yhteen moninaiset ja jopa vastakkaisilta tuntuvat taloudelliset, ympäristölliset, sosiaaliset ja kulttuuriset näkökulmat. Siksi se on mielenkiintoinen ehdokas myös maatalouspolitiikan viitekehykseksi. Kuinka kestävä kehitys ilmentyy EU:n yhteisen maatalouspolitiikan kehityshistoriassa? Entä tarjoaako se ratkaisuja ristiriitaisten näkökulmien yhteensovittamiseen?

Tässä artikkelissa tarkastellaan EU:n yhteisen maatalouspolitiikan ja kestävän kehityksen suhdetta. Kestävän kehityksen käsite tarjoaa mahdollisuuden taloudellisten, ympäristöllisten, sosiaalisten ja kulttuuristen näkökulmien systemaattiseen yhteensovittamiseen myös normatiivisena työkaluna eikä vain kuvaustapana poliittisia tavoitteita asetettaessa, suunniteltaessa ja arvioitaessa. Tutkimuskysymyksenä on, miten yhteisen maatalouspolitiikan kehitystä voidaan kehystää kestävän kehityksen käsitteen avulla. Aineistona analyysissä on käytetty EU:n keskeisten uudistusten valmistelumuistioita ja päätöksiä sekä niistä tehtyjä tiedotteita. Menetelmänä on käytetty valmiisiin kategorioihin perustuvaa sisällönanalyysiä (Hsieh \& Shannon 2005, 1281). Analyysi on suoritettu tunnistamalla uudistusten sisällöistä kestävän kehityksen eri ulottuvuuksien ilmentymiä. Tutkimusote on siis käsitteellinen ja historiallinen ja luonteeltaan tulkitsevaa analyysiä. Tulokset on kuvattu tiivistetysti yhteisen politiikan kehitystarinana kestävän kehityksen ilmentymien kautta. Tuloksista ei siis voida tehdä johtopäätöksiä politiikkakeinojen tosiasiallisesta kyvystä edistää kestävää kehitystä, ainoastaan kestävän kehityksen esiintymisestä politiikan perusteluissa ja ilmentymissä. Pidemmälle menevä analyysi vaatisi keinojen vaikutusten analyysiä ja asemointia 
kestävyysulottuvuuksille ja normatiivisten tarkastelupisteiden asettamista (alapuolella heikentää, yläpuolella vahvistaa kestävää kehitystä).

Artikkelissa tarkastellaan ensin kestävän kehityksen käsitettä maatalouselinkeinon ja maatalouspolitiikan kontekstissa. Tämän jälkeen kuvataan EU:n yhteisen maatalouspolitiikan tarina tämän viitekehyksen puitteissa ja esitetään analyysin tulokset. Lopuksi pohditaan sitä, kuinka käyttökelpoinen kestävän kehityksen käsite on tällaisen politiikanalan kehystämiseen sekä miten sitä voitaisiin hyödyntää edelleen politiikan suunnittelussa, tavoitteiden asettamisessa ja arvioinnissa.

\section{Kestävä kehitys ja maatalous}

Kestävän kehityksen käsite on utuinen ja jännitteinen. Kestävän kehityksen käsitteen tekee jännitteiseksi ja monitulkintaiseksi jo kestävyyden eli säilymisen ja kehityksen eli muutoksen yhdistäminen (vrt. Palviainen 2000, 20-21). Alkuperäisessä Brundtlandin (1987) lanseeraamassa muodossaan se kiteytyi ylisukupolviseen oikeudenmukaisuuteen, jossa tulevaisuuden ihmiskunnalta ei viedä mahdollisuutta tarpeidensa tyydyttämiseen. Esillä olivat tuolloin erityisesti maailman köyhimpien ihmisten perustarpeet ja kasvavat ympäristöongelmat (ibid.). Sittemmin kestävän kehityksen käsitteen ytimeen ovat nousseet ympäristökysymykset (Puupponen 2009). Ajan myötä kestävän kehityksen käsitteen käyttö on laajentunut ja sille on vakiintunut neljä sisällöllistä ulottuvuutta: sosiaalinen, ympäristöllinen, taloudellinen ja kulttuurinen. Nämä ulottuvuudet voidaan nähdä myös pääomalajeina, joiden tuottokyvyn säilyminen turvaa mahdollisuuden nauttia niiden tuottamista moninaisista hyödyistä myös tulevaisuudessa (Kuhmonen ym. 2015).

Maataloustuotanto perustuu luonnonvaroihin ja niiden hyödyntämisprosesseihin, minkä vuoksi ympäristöllinen kestävyys on olennaista ruuan tuotanto- ja kulutusmahdollisuuksien säilymiselle myös tuleville sukupolville. YK:n maatalous- ja elintarvikejärjestön FAO:n (2014) mukaan kestävä maatalous tähtää juuri tähän päämäärään luonnonvarojen säilyttämisen ja kestävän hallinnan sekä teknologian ja instituutioiden muutosten tuella. Maatalouden ympäristöllisen kestävyyden ytimessä ovat maan, veden sekä kasvien ja eläinten geneettisten varojen suojelu eli tuottokyvyn 
säilyttäminen. Kestävään maatalouteen kuuluvat myös tuotannosta aiheutuvien ympäristöhaittojen vähentäminen ja poistaminen (Horrigan ym. 2002, 452-453). Maatalouden ympäristöllinen kestävyys on usein kiinnitetty maahan, veteen, ilmaan ja luontoon erilaisin laatua, pilaantumista ja luonnon osalta myös monimuotoisuutta kuvaavin käsittein ja mittarein (esim. FAO 2013).

Sosiaalinen kestävyys liittyy vahvasti oikeudenmukaisuuteen, tasa-arvoon ja osallisuuteen (Duell 2013; Kautto \& Metso 2008). Maa- ja elintarviketalouden tapauksessa keskeinen osa sosiaalista kestävyyttä on mahdollisuus kohtuuhintaisen, terveellisen ja turvallisen ruuan saatavuuteen (FAO 2014; Räsänen ym. 2014). Tässä asiayhteydessä sosiaalinen kestävyys on läheistä sukua huoltovarmuudelle ja ruokaturvalle (Niemi ym. 2013). Rannikon (1999) mukaan sosiaaliseen kestävyyteen kuuluu myös hyötyjen ja haittojen oikeudenmukainen jakautuminen. Maatalouden tapauksessa tätä voitaisiin tarkastella esimerkiksi alueiden tai tuottajien ja kuluttajien/veronmaksajien välisenä asiana. Kulttuurinen kestävyys liitetään usein läheisesti sosiaaliseen kestävyyteen (Ilbery \& Maye 2005). Se ilmentää kulttuurisen pääoman säilymistä eli kulttuurista jatkuvuutta (Hangasmaa 2011, 67-69), perinteiden ja kulttuurimaiseman säilymistä (Puupponen 2009, 37) ja paikallisia arvoja kunnioittavaa kehitystä (Rannikko 1999, 398).

Taloudellinen kestävyys on elinkeinotoiminnan kannalta merkittävä mutta samalla epämääräisin ulottuvuus. Sitä on kuvattu tasapainoiseksi kasvuksi, joka ei perustu varantojen hävittämiseen tai velkaantumiseen (YM 2015) tai hyvinvoinnin tason ja sitä tuottavien varantojen säilymiseksi (Markulev \& Long 2013, 2-3) eli hyvinvoinnin ylläpitokapasiteetin ylisukupolviseksi säilymiseksi (Solow 1991, 3). Koska kasvu tai hyvinvointi kytkeytyy aina luonnonvaroihin, sosiaalisiin suhteisiin ja kulttuurievoluutioon, taloudellista kestävyyttä tarkastellaan harvoin irrallaan muista ulottuvuuksista (Kotro \& Järvinen 2014, 25). Kestävyyden tarkasteluyksikön ongelma on suurin juuri taloudellisessa kestävyydessä. Esimerkiksi lisääntyvän kaupungistumisen ja globalisaation oloissa tuotantohaitat ja kulutushyödyt voivat kohdistua eri alueille ja eri toimijoihin (Kuhmonen ym. 2015, 19; Rannikko 1999, 404). Usein tuontiruuan tuotantotapaa ei kuitenkaan edes tiedetä. Makrotasolla maatalouden taloudellinen kestävyys voisi tarkoittaa mahdollisuutta kulutustarvetta vastaavaan kannattavaan tuotantoon, mutta markkinataloudessa mikro- eli yritystason kannattavaa tuotantomahdollisuutta ei voida taata 
kenellekään. Tästä huolimatta monet taloudellisen kestävyyden mittarit kuvaavat juuri yritystason kannattavuutta ja jatkuvuutta (esim. FAO 2013).

Kestävän kehityksen käsite ja tavoite on intuitiivisesti selvä: ihmisen muuttuvien tarpeiden tyydyttäminen tulisi tapahtua taloudellisen kohtuuden, luonnon kantokyvyn, sosiaalisen oikeudenmukaisuuden ja kulttuurisen jatkuvuuden puitteissa siten, että näiden pääomavarantojen tuottokyky ei vähene. Täsmällisempi tarkastelu törmää kuitenkin moniin ongelmiin siitä, millaisia ovat näiden ulottuvuuksien tavoitetasot, mihin toimintaan ja mille toiminnan tasoille ne tulisi asettaa sekä miten niitä tulisi kohdentaa esimerkiksi eri alueiden ja toimijoiden erilaiset alkuvarannot huomioiden (esim. kehitysmaat vs. kehittyneet maat, kaupunkilaiset vs. maalaiset). Kestävälle kehitykselle on laadittu monenlaisia indikaattorijärjestelmiä yksittäisten mittareiden ongelmallisuuden vähentämiseksi (VNK 2015), mutta nämä eivät millään tavalla ratkaise tavoite- tai minimitasojen asettamisen ongelmaa tai kestävyyden ulottuvuuksien keskinäisiä suhteita. Yleisellä tasolla kestävää kehitystä esimerkiksi tietyn elinkeinon tai politiikanalan kohdalla on kuitenkin mahdollista arvioida esimerkiksi sen osalta, millaisia painotuksia kestävän kehityksen eri ulottuvuudet saavat.

\section{EU:n yhteisen maatalouspolitiikan tarina}

Euroopan yhteisen maatalouspolitiikan synty ajoittui toisen maailmansodan jälkeiseen jälleenrakennusprosessiin. Elintarvikehuollon hauraus ja haavoittuvuus oli yhteisessä muistissa. Vielä 1950-luvulla tulevat perustajavaltiot tuottivat useita maataloustuotteita kulutusta vähemmän; aliomavaraisuus koski erityisesti vehnää, maissia, kananmunia ja naudanlihaa. Toisaalta talouskasvun tuoma hyvinvointi vahvisti esimerkiksi Ranskan halua päästä maataloustuotteillaan ostovoimaisen Saksan markkinoille ja Saksan halua saada lisää markkinoita metalli- ja teollisuustuotteilleen (Tangermann \& von Cramon-Taubadel 2013, 17). Moninaisten neuvottelujen (Green Pool 1952-1954), konferenssien (Messina 1955) ja raporttien (Spaak 1956) jälkeen syntyi kuuden perustajavaltion kesken Rooman sopimus vuonna 1957 (Tracy 1989, 246-251).

Rooman sopimuksessa sovittiin yhteisen maatalouspolitiikan tavoitteet, mutta ei niiden toteuttamiskeinoja, jotka syntyivät vasta 1960-luvun aikana. 
Tavoitteisiin kuuluivat maatalouden tuottavuuden lisääminen ja sen kautta maatalousväestön kohtuullisen elintason takaaminen, elintarvikemarkkinoiden vakauttaminen, elintarvikehuollon turvaaminen sekä kohtuullisten elintarvikehintojen takaaminen (artikla 39.1). Politiikan keskiössä olivat siis tuottajat ja kuluttajat - laajan viljelijäväestön toimeentulo ja kohtuuhintaisen ruuan saatavuus. Yhteisen politiikan toimeenpanossa tuli kuitenkin ottaa huomioon maatalouden yhteiskunnallinen rakenne, alueelliset erot, sopeuttamistarve ja kytkeytyminen muuhun talouselämään (artikla 39.2). Kestävän kehityksen näkökulmasta esillä olivat ensisijaisesti taloudellinen ja sosiaalinen kestävyys eli ruuan tuotanto- ja kulutusmahdollisuuksien turvaaminen, toimeentulo ja alueiden erilaisuus (vrt. Pelkmans 1997, 164). Ympäristökysymykset eivät olleet tuolloin maatalouspolitiikan agendalla.

Yhteisen maatalouspolitiikan käytännön toteutus rakennettiin kolmen periaatteen eli yhteisten sisämarkkinoiden, yhteisöpreferenssin ja yhteisrahoituksen varaan (Harris ym. 1983, 39-40; Ritson 1991, 2). Yhteisillä sisämarkkinoilla tuotteiden tuli liikkua vapaasti ylijäämäalueilta alijäämäalueille. Yhteisöpreferenssi tarkoitti sisämarkkinatuotteiden suosimista; rajasuoja takasi omille tuotteille tuontituotteita korkeamman hinnan ja sisälsi samalla tukielementin yhteisön maataloudelle. Yhteisrahoitus tarkoitti sitä, että markkinajärjestelyt ja viljelijöiden tuet maksettiin EU:n maatalousbudjetista eli Euroopan maatalouden takuu- ja ohjausrahastosta. Yhteisen politiikan synnyn ja vakiintumisen aikoihin 1960-luvulla maatalous vei 85-100 \% koko EU:n budjetista (Bos 2011, 84-85).

Vapaat sisämarkkinat tukielementteineen ja teknologisen kehityksen siivittämä maatalouden tuottavuuden kasvu lisäsivät maataloustuotteiden tuotantoa (van der Zee 1997, 129). EU muuttuikin 1970- ja 1980-luvuilla maataloustuotteiden nettotuojasta nettoviejäksi (BAE 1985, 19). Yhteisön sisäisen suhteellisen edun periaate ei ollut toteutunut erikoistumisen periaatteella, vaan kaikki jäsenvaltiot olivat lisänneet eniten tuettujen tuotteiden tuotantoa (maissi, vehnä, liha, maito) ja vähentäneet vähemmän tuettujen tuotteiden tuotantoa (peruna, kaura, ruis; Kuhmonen 1991). Tuotanto kasvoi nopeasti suotuisimmilla viljelyalueilla eli Alankomaiden etelä- ja itäosissa, Belgian länsiosissa, Bretagnessa, Po-joen laaksossa, eteläisessä Englannissa, Saksan länsi- ja pohjoisosissa sekä Tanskan länsiosissa. Viljelyn voimaperäisyys sekä ympäristön ravinne- ja torjunta-ainekuormitus ovat olleet näillä 
alueilla suuria ja sen myötä esimerkiksi pohjavedet pahoin nitraattien saastuttamia (Dietz \& Heijnes 2010, 18; myös Bowler 1985).

Kulutuksen ylittävä tuotanto eli ylituotanto vaati korkean sisämarkkinahinnan ja alhaisen vientihinnan erotuksen korvaamista budjetista vientituella. Budjettipaineet kasvoivat ja vuodesta 1988 lähtien maatalousmenojen kasvulle alettiin asettaa kattoja (Bos 2011, 86). Maataloustuotantoa alettiin rajoittaa kiintiöillä ja markkinointimaksuilla, jotka laajenivat maidontuotannosta moniin muihinkin tuotteisiin 1980-luvun aikana. Esillä olivat myös politiikan haitalliset vaikutukset kehitysmaihin. Kehitysmaat eivät päässeet ostokykyisille EU-markkinoille kuin entisiä siirtomaita koskevan Lomén sopimuksen ja sittemmin Cotonoun sopimuksen puitteissa (Laaksonen ym. 2006) ja kärsivät EU:n vientituen painamista vientihinnoista. Kestävän kehityksen näkökulmasta politiikkamuutoksissa oli kysymys lähinnä sosiaalisesta kestävyydestä: oikeudenmukaisesta taakanjaosta tuottajien ja veronmaksajien kesken, jäsenvaltioiden eriytymisestä politiikasta hyötyviin ja sitä rahoittaviin ryhmiin sekä kehitysmaiden asemasta.

Edellä kuvatut muutokset olivat loppu yhteisen maatalouspolitiikan synty- ja kehitysvaiheen "autonomialle" ja alku sen liittämiselle osaksi laaja-alaisempaa yhteiskuntapolitiikkaa (Kuhmonen 2015, 19). Jo 1970luvulla liittyneiden pohjoisten jäsenvaltioiden (Iso-Britannia, Irlanti, Tanska) lisäksi yhteisöön tuli 1980-luvulla eteläisiä jäsenvaltioita (Kreikka, Espanja, Portugali) laajoine maaseutualueineen. Alueiden väliset erot kohosivat politiikan agendalle. Vuonna 1972 otettiin käyttöön investointi-, varhaiseläke- ja neuvontatuki, vuonna 1975 luotiin epäedullisten alueiden tukijärjestelmä (luonnonhaittakorvaus) ja 1980-luvulla syntyi koheesiopolitiikka aluekehitysohjelmineen ja ohjelmakausineen. Maataloustuotannon jatkuvuus haluttiin turvata myös syrjäisemmillä alueilla sen työllisyys- ja ympäristöhyötyjen vuoksi (direktiivi 75/268). Samalla alueiden välisiä sosio-ekonomisia eroja haluttiin tasata (Clout 1984). Yhteinen maatalouspolitiikka oli 1970- ja 1980-luvun vahvasti sosiaalisen kestävyyden asialla ja "halusi auttaa niitä jotka halusivat tulla autetuiksi" (Commission 1972, 2).

Maailman kauppajärjestön (GATT/WTO) kansainvälisen kaupan vapauttamista koskevat monenkeskiset neuvottelut tuottivat maatalouden kannalta ensimmäisen merkittävän sopimuksen Uruguayn kierroksella 1986-1994. Sopimuksessa päätettiin siirtymisestä vakaan sisämarkkinahintatason takaavista tuontimaksuista vähitellen alennettaviin tullimaksuihin, 
vientitukien vähentämisestä ja kauppaan vaikuttavien tukien rajoittamisesta. Niin sanottuun vihreään laatikkoon (green box) sisältyvät tuet, kuten ruoka-apu, koulutus sekä tuotantoon kytkemätön tulo- ja ympäristötuki, jätettiin alentamisvelvoitteiden ulkopuolelle (WTO 2003, 10-11).

Näihin velvoitteisiin vastaaminen sekä budjetti- ja ympäristöpaineet (Commission 1991) käynnistivät vuonna 1992 maatalouskomissaari MacSharryn nimeä kantavalla yhteisen maatalouspolitiikan uudistuksella uuden kehityspolun. Kehityspolulle on ollut ominaista tuottajahintojen alentaminen kohti maailmanmarkkinahintatasoa ja menetysten korvaaminen viljelijöille tuotantovälineistä, kuten kotieläimistä ja erityisesti peltohehtaareista, maksettavalla ehtoja sisältävällä tuella (OECD 2011, 138). Viljelijöistä haluttiin tehdä ruuantuottaja-ympäristönhoitajia (vrt. Commission 1991, 10). Nämä suuret periaatteelliset muutokset mahdollistivat paitsi sopimusvelvoitteiden täyttämisen ja budjettipaineiden helpottumisen myös politiikkatoimien aiempaa vahvemman otteen itse maataloustuotannosta, kun budjettituille saatettiin asettaa ehtoja tuen saamiseksi. Aiemmin valtaosan maatalousbudjetista vieneet interventio-ostot, varastointi ja vientituki eivät tällaista mahdollistaneet ja toisaalta suoraan maatiloille maksettavat tuet olivat joko määrältään hyvin vähäisiä (investointituet) tai ehdoiltaan väljiä (luonnonhaittakorvaus). Maatalousbudjetti painui alle puoleen EU:n kokonaismenoista (Bos 2011, 85-86).

Vuonna 1991 luotiin luonnonmukaista tuotantoa (luomu) koskeva lainsäädäntö (asetus 2092/91). Vuonna 1992 käynnistyi maatalouden ympäristötukijärjestelmä (asetus 2078/92), joka keskittyi maatalouden ympäristökuormituksen vähentämiseen. Se oli ensimmäinen jäsenvaltiolle pakollinen maatalouden ympäristötoimenpide (OECD 2011, 152). Samana vuonna päätettiin myös maataloustuotteiden nimisuojajärjestelmästä, joka vahvisti kulttuurista kestävyyttä suojaamalla perinteisten tuotteiden alkuperää ja tuotantotapaa (Commission 2015). Vuonna 2010 nimisuojattujen tuotteiden tukkumyynnin arvo oli 54 miljardia euroa ja osuus EU:n elintarvikeviennistä kolmansiin maihin oli 15 prosenttia (Tanguy ym. 2012, 4, 19).

Yhteisessä maatalouspolitiikassa jatkui aikakausi, jossa budjetista maksettavien tukien määrä kasvoi samalla kun niihin liittyvät tavoitteet monipuolistuivat. Myös hakemiseen, maksatukseen ja valvontaan liittyvä byrokratia alkoi paisua samassa tahdissa. Vuonna 1999 sovittiin Agenda 2000 -uudistuksesta, jonka ydinkäsitteitä olivat monivaikutteinen maatalous ja "kestävän 
maatalouden eurooppalainen malli" (Commission 1999, 6). Maatalouden haitallisia ulkoisvaikutuksia (ravinnepäästöt) haluttiin vähentää ja maataloustuotannon yhteydessä syntyvien julkishyödykkeiden (maisema, kulttuuriperintö) saatavuus haluttiin turvata. Yhteinen maatalouspolitiikka jaettiin kahteen pilariin: elintarviketuotantoon keskittyvään markkinapolitiikkaan sekä ympäristö- ja maaseututoimintoihin keskittyvään maaseudun kehittämispolitiikkaan. Tuottajahintoja alennettiin, tulotukia korotettiin ja ympäristö- ja maaseututukien määrää lisättiin. Taloudellinen, ympäristöllinen ja sosiaalinen kestävyys olivat vahvasti mukana, vaikkakin vain maatalouden eurooppalaisen mallin osatekijöinä.

Komissaari Fischlerin nimeä kantavassa uudistuksessa vuonna 2003 tuet irrotettiin lopullisesti tuotantomääristä (decoupling), ympäristöä, elintarviketurvallisuutta ja eläinten hyvinvointia koskevien velvoitteiden noudattaminen kytkettiin tukiehdoksi (cross-compliance) ja isoilta tiloilta leikattiin tukia, mistä säästyneet varat siirrettiin maaseudun kehittämistoimenpiteisiin (modulation). Jo edellisenä vuonna oli säädetty elintarvikelaki ja perustettu Euroopan elintarviketurvallisuusvirasto vuoden 1996 niin sanotun hullun lehmän taudin jälkimainingeissa. Hintojen laskua korvaavat tulotuet muuttuivat entistä vastikkeellisemmiksi; vastike koostui elintarvikkeiden laadusta, ympäristönsuojelusta, eläinten hyvinvoinnista, maiseman ja kulttuuriperinnön vaalimisesta, parantuvasta sosiaalisesta tasapainosta sekä oikeudenmukaisuudesta (Commission 2002). Tukien ehdot muuttivat viljelijöiden kannusteita, mutta samalla lukitsivat vinon tukijakauman jäsenvaltioiden ja tuottajien välillä, koska tuet perustuivat aiempaan tuotanto- ja tukimäärään. Uudistuksen perusteissa olivat mukana kaikki kestävän kehityksen ulottuvuudet, mutta alueiden ja viljelijöiden näkökulmasta oikeudenmukaisuus toteutui vain historiallisesta näkökulmasta (tulomenetykset korvattiin) eikä toimintamahdollisuuksien näkökulmasta (parhaat saivat eniten tukea).

Yhteisen maatalouspolitiikan terveystarkastus vuonna 2008 (Commission 2010) ohensi markkinainterventioita (esim. maitokiintiöiden poisto 2014/2015, interventio-ostoista vain turvaverkko) ja vahvisti yhteiskunnallisia näkökulmia. Isoilta tiloilta leikattiin lisää tukea ja varat ohjattiin EU:n ilmastonmuutoksen torjuntatavoitteiden edistämiseen maataloudessa (Commission 2007, 14). Myös Keski- ja Itä-Euroopan uudet jäsenvaltiot, erityisvaikeuksista kärsivät tuotannonalat ja nuoret viljelijät saivat lisätukea. Uudistusta leimasivat taloudellisen (erityiset vaikeudet), sosiaalisen (uudet 
jäsenvaltiot, modulaatio, nuoret) ja ympäristöllisen kestävyyden (ilmastotavoitteet) ilmentymät.

Viimeisimmässä, vuoden 2013 jälkeistä aikaa koskeneessa politiikkauudistuksessa päähuomio on budjettitukien uudistamisessa. Jäsenvaltioissa siirrytään kohti alueellista tai kansallista tasatukea, isoilta tiloilta leikataan tukea ja nuorille viljelijöille, pienille tiloille ja epäedullisille tuotantoalueille maksetaan lisätukea. Myös jäsenvaltioiden välisiä tukitasoeroja tasataan merkittävästi vuoteen 2020 mennessä. Tuet "vihertyvät" (greening), sillä tilatuen saamisen ehtona on viljelykasvien määrän monipuolistaminen, pysyvän nurmen säilyttäminen ja tilakohtaisen luonnonhoitoalan perustaminen (Commission 2013a, 2013b). Politiikkauudistuksessa painottuivat kestävän kehityksen sosiaalinen ja ympäristöllinen ulottuvuus.

Yhteisen maatalouspolitiikan lähitulevaisuuden haasteet liittyvät muun muassa ilmastonmuutoksen torjuntaan ja siihen sopeutumiseen, laadullisiin tekijöihin ja kasvavan sisäisen erilaisuuden hallintaan (esim. Buckwell 2014; Commission 2013a; Marsden \& Morley 2014). Ohjelmakaudella 20142020 ilmastohaasteisiin pyritään vastaaman lakisääteisillä vaatimuksilla, edellä kuvatulla viherryttämistuella sekä maaseudun kehittämisohjelmilla, joissa vähintään $30 \%$ varoista täytyy kohdentaa ympäristö- ja ilmastotoimenpiteisiin. Sen jälkeen, kun omavaraisuus tärkeimmissä elintarvikkeissa saavutettiin 1980-luvulla, huomio on alkanut suuntautua enemmän tuotannon laadullisiin tekijöihin, ruuan tuotannon, kulutuksen ja politiikan vaikutuksiin sekä markkinavaihteluiden kasvun myötä myös ruokaturvaan. EU:ssa onkin vahvistumassa laajemman ruokapolitiikan käsite, jolla pyritään vahvistamaan tuottajien asemaa ja sopeutumiskykyä markkinavaihteluihin, kuluttajien luottamusta ja osallisuutta, tuoteturvallisuutta, laatua ja kestävää kehitystä (esim. asetus 1151/2012 laatujärjestelmistä; Commission 2013a; Kneafsey ym. 2013).

\section{Tulokset}

Edellä esitetyn kuvauksen perusteella yhteisen maatalouspolitiikan kehitystä voidaan luontevasti tulkita kestävän kehityksen käsitteen viitekehyksessä (taulukko 1). EU:n maatalouspolitiikan tarina on kestävän kehityksen näkökulmasta tarkasteltuna ensisijaisesti tarina yhteiskunnan 
maataloustuotantoon liittämien tavoitteiden ja keinojen monipuolistumisesta. Alkuvaiheessa 1960-luvulla olivat mukana toimeentuloon sekä ruuan saatavuuteen ja hintaan liittyvät taloudelliset ja sosiaaliset näkökulmat, kun omavaraisuutta ja ruokaturvaa haluttiin parantaa sodan jälkeisessä tilanteessa. Ympäristönäkökulma tuli ensimmäistä kertaa esille merkittävissä politiikkauudistuksissa 1970-luvun puolivälissä, kun haluttiin turvata erityisesti vuoristoalueiden luonnonhaitoista kärsivien mutta ympäristöllisesti arvokkaiden alueiden maataloustuotannon säilyminen ja perinnemaisemien hoito. Varsinainen "ympäristökäänne" yhteisessä maatalouspolitiikassa tapahtui 1990-luvun alussa kaikkia jäsenvaltioita velvoittavien nitraatti- ja luomudirektiivien sekä maatalouden ympäristötuen käyttöönoton myötä. Kulttuurisen kestävyyden ensimmäinen merkittävä ilmentymä oli elintarvikkeiden nimisuojajärjestelmän perustaminen 1990-luvun alussa. 1990-luvulta alkaen toteutetuissa maatalouspolitiikan uudistuksissa ovat olleet yhtä aikaa esillä useimmat kestävyysnäkökulmat. Viimeisimmissä uudistuksissa on mainittu kestävyys myös eksplisiittisesti. Esimerkiksi vuoden 2013 uudistuksen tavoitteissa keskityttiin "maatalouselinkeinon kilpailukykyyn ja kestävyyteen" (Commission 2013a, 2, 5) sekä pyrittiin vastaamaan niin taloudellisiin (ruokaturva, globalisaatio, heikkenevä tuottavuus, kasvavat tuotantokustannukset, viljelijöiden heikentyvä asema elintarvikeketjussa), ympäristöllisiin (resurssitehokkuus, maaperän ja veden laatu, uhat elinympäristöille ja luonnon monimuotoisuudelle) kuin alueellisiin kestävyyshaasteisiin (maaseutualueiden väestölliset, taloudelliset ja sosiaaliset muutokset kuten väestökato ja liiketoiminnan uudelleensijoittuminen).

Poliittisen taloustieteen viitekehyksessä tarina heijastaa myös julkisten politiikkatoimenpiteiden kehityksen urariippuvuutta sekä erilaisten yhteiskunnallisten huolenaiheiden, intressien ja tietoisuuden voimakenttien vaikutusta (Halcrow ym. 1994, 33). Kestävän kehityksen käsittein yhteinen maatalouspolitiikka on muuttunut moniulotteisemmaksi. Viimeisimmillä uudistuksilla on yleensä tavoiteltu sekä kestävyyden taloudelliseen, ympäristölliseen, sosiaaliseen että kulttuuriseen ulottuvuuteen liittyviä muutoksia. Kestävä kehitys ei ole ollut eksplisiittisesti uudistusten perusta varsinkaan politiikan alkuvaiheissa (koska käsitettä ei ollut edes olemassa), mutta lukuisilla maatalouspolitiikan omilla käsitteillä on kuvattu ja tavoiteltu kestävän kehityksen ideaalia. Kestävän kehityksen ulottuvuuksien välisiä yhteyksiä 


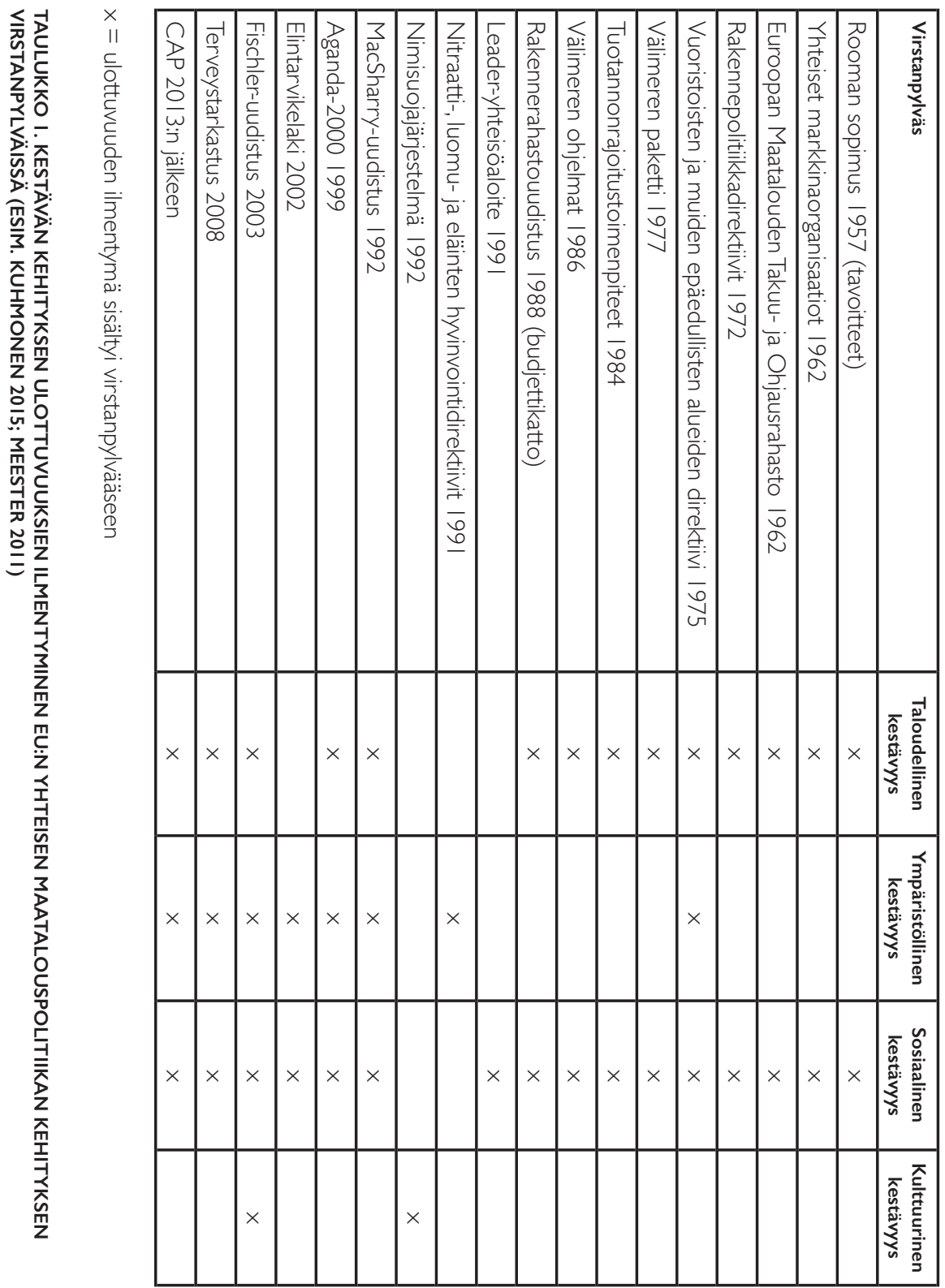


ei ole kuitenkaan jäsennelty uudistuksia suunniteltaessa kovin yksityiskohtaisesti.

\section{Keskustelua}

Kestävän kehityksen käsitettä voitaisiin hyödyntää eksplisiittisesti yhteisen maatalouspolitiikan suunnittelussa, tavoitteiden asettamisessa ja arvioinnissa. Yhteisen politiikan alkutaipaleella huomio oli ymmärrettävistä syistä sosio-ekonomisissa haasteissa, eikä sen ohjaaman kehityksen mahdollisia ympäristöllisiä vaikutuksia ennakoitu lainkaan. Tämä johti moniin paikallisiin ympäristöongelmiin. Kun nykyinen politiikkapainotus taas ohjaa laatimaan monenlaisia ympäristönormeja, raja-arvoja ja vaatimuksia, niiden sosiaaliset vaikutukset jäävät usein huomiotta. Tämä on johtanut siihen, että tuotannon lopettajien joukossa on myös suuria ja elinkelpoisia tiloja, kun osa vaatimuksista on koettu merkityksettömiksi kestävyydelle, eikä raskaan valvontabyrokratian kanssa pelaaminen enää huvita. Politiikkaa ei siis koeta hyväksyttäväksi eli legitiimiksi. Ongelmat johtuvat osin siitä, että yhteinen maatalouspolitiikka ei toimi "laboratorio-olosuhteissa", vaan ensisijaisesti erilaisten kansallisten, taloudellisten ja ideologisten intressien poliittisena sulatusuunina (Tangermann \& von Cramon-Taubadel 2013, 51). Kestävän kehityksen käsitteen suurin hyöty voisikin olla eräänlaisena metatason viitekehyksenä, joka ohjaisi huomioimaan yhtä aikaa taloudellisen, ympäristöllisen, sosiaalisen ja kulttuurisen ulottuvuuden yhteydet sekä etsimään keinoja yhteensopivuuksien hyödyntämiselle ja ristiriitaisuuksien ratkaisemiselle "ylemmällä tasolla". Tämä oli kantavana ajatuksena myös Brundtlandilla (1987, 6-7).

Metatason viitekehyksenä kestävä kehitys nostaa esille ulottuvuuksien ajallisen, sisällöllisen ja keskinäisen dynamiikan ja riippuvuuden. Ratkaistaessa yhteiskunnassa kulloinkin ongelmallisina pidettyjä maatalouteen ja ruokahuoltoon liittyviä kysymyksiä, kestävän kehityksen viitekehyksen avulla voidaan systemaattisesti ohjata asettamaan esimerkiksi tavoitteet, arvioimaan käytettäviä keinoja ja ennakoimaan vaikutuksia yhtä aikaa sekä taloudellisen, ympäristöllisen, sosiaalisen että kulttuurisen ulottuvuuden osalta. Kun pohditaan esimerkiksi maatalouden ympäristönormien kiristämistä ja ympäristöllisen kestävyyden vahvistamista, voidaan samalla 
arvioida sen taloudellisia vaikutuksia viljelijöiden toimeentulolle ja ruuan hinnalle, sosiaalisia vaikutuksia eri väestöryhmille ja alueille sekä kulttuurisia vaikutuksia erilaisille viljelykulttuureille. Nyt etenkin maa- ja elintarviketalouden ympäristövaikutuksia koskeva tutkimus on muista irrallaan oleva saareke, jossa näitä yhteyksiä pohditaan niukasti (Kuhmonen ym. 2015, 31). Tämä näyttää pätevän myös yleisemmin kestävyyden tieteellisessä tutkimuksessa: ympäristöulottuvuutta tutkitaan eniten, mutta irrallaan muista ulottuvuuksista (Schoolman ym. 2012, 76).

Kestävyyden ulottuvuuksien yhdistelmät tuottavat runsaasti hyödyllisiä kysymyksiä, joista on apua politiikan tavoitteiden asettamisessa ja suunnittelussa ja arvioinnissa. Esimerkiksi ympäristöllisen kestävyyden ja sosiaalisen oikeudenmukaisuuden yhdistelmä ohjaa kysymään ympäristötoimenpiteiden alueellisen kohdentamisen tarvetta ja perustetta eri aluetasoilla. Kun monet maatalouden päätuotantoalueet ovat jo pilanneet ympäristöään merkittävästi, voidaan kysyä, että pitäisikö niille asettaa EU:n ympäristöpolitiikan lähtökohtana olevan saastuttaja maksaa -periaatteen (Scheuer 2006, 81) mukaisesti muita tiukemmat ympäristöllisen kestävyyden vaatimustasot tai jättää ne kokonaan ilman ympäristötukea? Entä miten tuotantohaittojen ja kulutushyötyjen erilainen kohdentuminen ylipäätään ratkaistaan sosiaalisesti kestävällä tavalla? Kysymyksenasetteluja ja valinta-asetelmia syntyy toki myös ulottuvuuksien sisällä. Laajaperäisen maataloustuotannon katsotaan usein edistävän ympäristöllistä kestävyyttä, mutta toisaalta ihmiskunnan ruokkiminen ilman voimaperäistä viljelyä edellyttäisi laajojen metsäalueiden hakkuutta ja ottamista viljelykäyttöön, millä olisi merkittäviä haitallisia vaikutuksia luonnon monimuotoisuuteen, vesistöihin ja ilmastonmuutokseen (FAO 2014).

Tällaista metatason tarkastelua pidemmälle mentäessä kestävän kehityksen käsitteen käyttökelpoisuus heikkenee olennaisesti. Kestävälle kehitykselle on vaikea asettaa järkeviä materiaalisia raja-arvoja ja yksinkertaisia mittareita, kuten erilaisia "jalanjälkiä" (Fiala 2008), koska ne peittävät tai ohittavat monia kestävyyden kannalta merkittäviä tekijöitä. Jos tällaisia raja-arvoja asetettaisiin, sellaisia tulisi pystyä asettamaan kestävyyden kaikille neljälle ulottuvuudelle yhtä aikaa, koska muuten ei olisi kyse kestävästä kehityksestä. Kestävän kehityksen käsite sisältää erittäin paljon ristikkäisvaikutuksia ulottuvuuksien välillä ja laadullisia tekijöitä. Kestävän kehityksen alkuperäinen idea oli kestävyyden ja kehityksen dynaaminen 
liitto, johon liittyvien tavoitteiden tarkoituksenmukainen suhde ja taso voi vaihdella kontekstista toiseen (vrt. Brundtland 1987) - kuten EU:n yhteisen maatalouspolitiikan tarinakin osoittaa. Lisäksi esimerkiksi nykyiset maatalouden ympäristöongelmat on voitu tulevaisuudessa ratkaista ja uudet sosiaaliset ongelmat ovat saattaneet nousta elintarvikehuollon ydinasiaksi.

Kestävä kehitys on erilaista eri mittakaavoissaan (mikro-makro) sekä paikallisissa ja ajallisissa konteksteissaan. Tämän vuoksi kuhunkin tarpeeseen sovellettavat politiikan tavoitteet, keinot ja arviointiperusteet tulisi johtaa systemaattisesti metatason ideaalista kaikki ulottuvuudet huomioiden pikemminkin kuin sidottuna irrallisiin yhden ulottuvuuden tarkasteluihin tai kapea-alaisiin, pelkistettyihin mittareihin. Ulottuvuuksille on vaikea löytää yhteistä mittaria, jotta niiden keskinäistä korvaavuutta olisi mahdollista tarkastella (vrt. Renning \& Wiggering 1997). Politiikkakeinojen systemaattinen suunnittelu ja arviointi yhtä aikaa kestävän kehityksen neljän ulottuvuuden osalta tekisi politiikan vaikutusten moniulotteisuuden paremmin ymmärretyksi. Julkinen politiikka vastaa aina yhteiskunnan kannalta merkittävinä pidettyihin haasteisiin, joten painotukset ulottuvuuksien välillä voivat vaihdella ajan saatossa. Yhteisen maatalouspolitiikan alkuvaiheissa huomio oli niin vahvasti taloudellisissa ja sosiaalisissa haasteissa ja niihin vastaamisessa, ettei politiikan ympäristövaikutuksia tarkasteltu riittävästi. Tällä hetkellä vaikuttaa siltä, että politiikan sosiaalisia vaikutuksia ei tarkastella riittävästi esimerkiksi viljelijöille kertyneen byrokratiataakan osalta. Systemaattisella neljän ulottuvuuden käytöllä osa ongelmista olisi voitu ehkä välttää ja osa tulevista ongelmista voitaisiin huomata politiikan suunnitteluvaiheessa.

\section{Lähteet}

Anderson, Kym ja Hayami, Yujiro (toim.). 1986. The political economy of agricultural protection: East Asia in international perspective. Sydney: Allen \& Unwin.

BAE. 1985. Agricultural policies in the European Community: Their origins, nature and effects on production and trade. Policy monograph 2. Canberra: Bureau of Agricultural Economics. 
Barrett, Christopher B., Cater, Michael R. ja Timmer, Peter C. 2010. A centurylong perspective on agricultural development. American Journal of Agricultural Economics, 92:2, 447-468.

Bos, Marko. 2011. The EU budget. Teoksessa Arie Oskam, Gerrit Meester ja Huib Silvis (toim.), EU policy for agriculture, food and rural areas. Second, revised edition. Wageningen: Wageningen Academic Publishers, 79-96.

Bowler, Ian R. 1985. Agriculture under the Common Agricultural Policy. Manchester: Manchester University Press.

Brundtland, Gro Harlem. 1987. Report of the world commission on environment and development: Our common future. New York: Yhdistyneet kansakunnat.

Buckwell, Allan. 2014. Some thoughts on the CAP post 2020. Memo. Lontoo: Institute for European Environmental Policy.

Clout, Hugh. 1984. A rural policy for the EEC? Lontoo: Methuen.

Commission. 1972. A new Common Agricultural Policy? Social and structural reform in agriculture. Newsletter on the Common Agricultural Policy 3, X/443/72-E. Bryssel: Commission of the European Communities.

Commission. 1991. The development and future of the CAP: Reflections paper of the Commission. COM (91) 100 final. Bryssel: Commission of the European Communities.

Commission. 1999. Directions towards sustainable agriculture. Communication from the Commission. COM (1999) 22 final. Bryssel: Commission of the European Communities.

Commission. 2002. "Towards sustainable farming": Commission presents EU farm policy mid-term review. IP/02/1026. European Commission, Brussels.

Commission. 2007. Adapting to climate change in Europe: Options for EU action. Communication from the Commission to the European Council. Green paper. COM (2007) 354 final. Byssel: European Commission.

Commission. 2010. Overview of the CAP Health Check and the European Economic Recovery Plan: Modifications of the RDPs. Fact sheet. Bryssel: European Commission. 
Commission. 2013a. Overview of CAP reform 2014-2020. Agricultural Policy Perspectives Brief 5/2013. Bryssel: European Commission.

Commission. 2013b. Political agreement on new direction for Common Agricultural Policy. IP/13/613. Bryssel: European Commission.

Commission 2015. Geographical indications and traditional specialities. European Commission, Brussels. Saatavissa: http://ec.europa.eu/agriculture/quality/ schemes/index_en.htm [Luettu 8.11.2015]

de Gorter, Harry ja Swinnen, Johan. 2002. Political economy of agricultural policy. Teoksessa Bruce L. Gardner ja Gordon C. Rausser (toim.), Handbook of agricultural economics 2a: Agriculture and its external linkages. Amsterdam: Elsevier, 1893-1943.

Dietz, Paul ja Heijnes, Haddeke. 1995. Nutrien emissions form agriculture: An alternative for the current abatement policies in EU countries. Teoksessa Frank J. Dietz, Herman R. J. Vollebergh ja Jan L. de Vries (toim.), Environment, incentives and the Common Market. Dordrect: Kluwer Academic Publishers, $15-36$.

Duell, Rebecca. 2013. Is 'local food' sustainable? Localism, social justice, equity and sustainable food futures. New Zealand Sociology, 28:4, 123-144.

FAO. 2013. Sustainability Assessment of Food and Agriculture Systems SAFA, Indicators. Food and Agriculture Organization for the United Nations, Rome. http://www.fao.org/fileadmin/templates/nr/sustainability_pathways/docs/ SAFA_Indicators_final_19122013.pdf [Luettu 8.11.2015].

FAO. 2014. Sustainable agriculture and rural development. Food and Agriculture Organization for the United Nations, Rome. http://www.fao.org/docrep/ u8480e/u8480e0l.htm. [Luettu 8.11.2015]

Fiala, Nathan. 2008. Measuring sustainability: Why the ecological footprint is bad economics and bad environmental science. Ecological Economics, 67:1, $519-525$.

Halcrow, Harold, Spitze, Robert ja Allen-Smith, Joyce. 1994. Food and agricultural policy: Economics and politics. New York: McGraw-Hill.

Hangasmaa, Leena. 2011. Maanviljelyn kulttuurinen kestävyys: Määrittelyn ja mittaamisen haasteita. Maaseudun uusi aika, 19:1, 61-70. 
Hanley, Nick, Shogren, Jay ja White, Ben. 2001. Introduction to environmental economics. Oxford: Oxford University Press.

Harris, Simon, Swinbank, Alan ja Wilkinson, Guy. 1983. The food and farm policies of the European Community. Chichester: John Wiley \& Sons.

Horrigan, Leo, Lawrence, Robert S. ja Walker, Polly. 2002. How sustainable agriculture can address the environmental and human health harms of industrial agriculture. Environmental Health Perspectives, 110:5, 445-456.

Hsieh, Hsiu-Fang ja Shannon, Sarah E. 2005. Three approaches to qualitative content analysis. Qualitative Health Research, 15:9: 1277-1288.

Ilbery, Brian ja Maye, Damian. 2005. Food supply chains and sustainability: Evidence from specialist food producers in the Scottish/English borders. Land Use Policy, 22:4, 331-344.

Kautto, Mikko ja Metso, Laura. 2008. Sosiaalinen kestävyys: Uusi poliittinen horisontti? Yhteiskuntapolitiikka, 73:4, 411-420.

Kneafsey, Moya, Venn, Laura, Schmutz, Ulrich, Balázs, Bálint, Trenchard, Liz, Eyden-Wood, Trish, Bos, Elizabeth, Sutton, Gemma ja Blackett, Matthew. 2013. Short food supply chains and local food systems in the EU: A state of play of their socio-economic characteristics. Report 25911. Sevilla: Joint Research Centre, Institute for Prospective Technological Studies, European Commission.

Kotro, Jaana ja Järvinen, Maija. 2014. Taloudellinen kestävyys. Teoksessa Katri Joensuu, Maija Järvinen ja Taija Sinkko (toim.), Biotalousketjujen ekologinen, sosiaalinen ja taloudellinen kestävyys. Raportti 184. Jokioinen: Maa- ja elintarviketalouden tutkimuskeskus, 25-26.

Kuhmonen, Tuomas. 1991. Mahdollisen EY-jäsenyyden rakenteelliset vaikutukset Suomen maataloudessa. PTT-katsaus 4/1991. Pellervon taloudellinen tutkimuslaitos, Espoo, 5-17.

Kuhmonen, Tuomas. 2015. Rural futures. Publications 1/2015. Turku: Finland Futures Research Centre, University of Turku.

Kuhmonen, Tuomas, Hyvönen, Katja, Ahokas, Ira, Kaskinen, Juha ja Saarimaa, Riikka. 2015. Paikallinen ruoka ja kestävä kehitys: kirjallisuuskatsaus. e-julkaisuja 7/2015. Turku: Tulevaisuuden tutkimuskeskus, Turun yliopisto. 
Laaksonen, Kalle, Mäki-Fränti, Petri ja Virolainen, Meri. 2006. Lomé conventions, agriculture and trade relations between the EU and the ACP countries in 1975-2000. Working papers 89. Espoo: Pellervo Economic Research Institute.

Markulev, Ana ja Long, Anthea. 2013. On sustainability: An economic approach. Productivity Commission Staff Research Note. Canberra: Australian Government.

Marsden, Terry ja Morley, Adrian. 2014. Current food questions and their scholarly challenges: Creating and framing a sustainable food paradigm. Teoksessa Terry Marsden ja Adrian Morley (toim.), Sustainable food systems: Building a new paradigm. Oxford: Routledge, 1-29.

Meester, Gerrit. 2011. European integration and its relevance for agriculture, food and rural areas. Teoksessa Arie Oskam, Gerrit Meester ja Huib Silvis (toim.), EU policy for agriculture, food and rural areas. Second, revised edition. Wageningen: Wageningen Academic Publishers, 29-43.

Niemi, Jyrki, Knuuttila, Marja, Liesivaara, Petri ja Vatanen, Eero. 2013. Suomen ruokaturvan ja elintarvikehuollon nykytila ja tulevaisuuden näkymät. Raportti 80. Jokioinen: Maa- ja elintarviketalouden tutkimuskeskus MTT.

OECD. 2011. Evaluation of the agricultural policy reforms in the European Union. Pariisi: OECD Publishing.

OECD. 2013. Agricultural policy monitoring and evaluation 2013: OECD countries and emerging economies. Pariisi: OECD Publishing.

Palviainen, Simo. 2004. Uusi sopimuksellisuus ympäristöpolitiikan välineenä: Toimintatutkimus ympäristöhallinnon ja maaseudun kohtaamisesta. Joensuun yliopiston yhteiskuntatieteellisiä julkaisuja 70. Joensuu: Joensuun yliopisto.

Pelkmans, Jacques. 1997. European Integration: Methods and economic analysis. Harlow: Addison Wesley Longman.

Puupponen, Antti. 2009. Maaseutuyrittäjyys, verkostot ja paikallisuus: Tapaustutkimus pienimuotoisen elintarviketuotannon kestävyydestä KeskiSuomessa. Jyväskylä Studies in Education, Psychology and Social Research 374. Jyväskylä: Jyväskylän yliopisto. 
Rannikko, Pertti. 1999. Combining social and ecological sustainability in the Nordic forest periphery. Sociologia Ruralis 39:3, 394-410.

Rennings, Klaus ja Wiggering, Hubert. 1997. Steps towards indicators of sustainable development: Linking economic and ecological concepts. Ecological Economics, 20:1, 25-36.

Ritson, Christopher. 1991. Introduction to the CAP. Teoksessa Christopher Ritson ja David Harvey (toim.), The Common Agricultural Policy and the world economy: Essays in honour of John Ashton. Oxford: CAB International, $1-9$.

Räsänen, Kati, Saarinen, Merja, Kurppa, Sirpa, Silvenius, Frans, Riipi, Inkeri, Nousiainen, Riikka, Erälinna, Leena, Mattinen, Laura, Jaakkola, Sirkka, Lento, Sanna ja Mäkinen-Hankamäki, Sari. 2014. Lähiruuan ekologisten vaikutusten selvitys. Raportti 145. Jokioinen: Maa- ja elintarviketalouden tutkimuskeskus MTT.

Scheuer, Stefan (toim.). 2006. EU environmental policy handbook: A critical analysis of EU environmental legislation. Bryssel: European Environmental Bureau.

Schoolman, Ethan D., Guest, Jeremy S., Bush, Kathleen, F. ja Bell, Andrew, R. 2012. How interdisciplinary is sustainability research? Analyzing the structure of an emerging scientific field. Sustainability Science, 7:1, 67-80.

Silvasti, Tiina. 2012. Ruokapolitiikka: ekologisen ja sosiaalisen yhteyksiä etsimässä. Teoksessa Tuija Mononen ja Tiina Silvasti (toim.), Hyvä ja paha ruoka: ruoan tuotannon ja kuluttamisen vaikutukset. Helsinki: Gaudeamus, 26-46.

Solow, Robert. 1991. Sustainability: An economist's perspective. The Eighteenth J. Seward Johnson Lecture. Woods Hole, MA: Woods Hole Oceanographic Institution.

Stiglitz, Joseph E. 1987. Some theoretical aspects of agricultural policies. World Bank Observer, 2:1, 43-60.

Swinnen, Johan. 2010. The political economy of agricultural and food policies: Recent contributions, new insights, and areas for further research. Applied Economic Perspectives and Policy, 32:1, 33-58. 
Tangermann, Stefan ja von Cramon-Taubadel, Stephan. 2013. Agricultural policy in the European Union: An overview. Diskussionsbeitrag 1302. Göttingen: Universität Göttingen.

Tanguy, Chever, Renault, Christian, Renault, Séverine ja Romieu, Violaibe. 2012. Value of production of agricultural products and foodstuffs, wines, aromatised wines and spirits protected by a geographical indication (GI). Final report. Pariisi: AND-International.

Tracy, Michael 1989. Government and agriculture in Western Europe 1880-1988. 3. painos. Hemel Hampstead: Harvester Wheatsheaf.

van der Zee, Frans A. 1997. Political economy models and agricultural policy formation: Empirical applicability and relevance for the CAP. Mansholt studies 8. Wageningen: Wageningen Agricultural University.

VNK [Valtioneuvoston kanslia]. 2015. Kestävän kehityksen indikaattorit. Valtioneuvoston kanslia ja Tilastokeskus. Saatavissa: http://www.findikaattori. fi/fi/kestavakehitys [Luettu 8.11.2015]

WTO [World Trade Organization]. 2003. Agriculture. The WTO agreement series 3. Geneve: Maailman kauppajärjestö.

YM. 2015. Kestävä kehitys. Helsinki: Ympäristöministeriö. http://www.ym.fi/ fi-FI/ymparisto/Kestava_kehitys/Mita_on_kestava_kehitys [Luettu 8.11.2015] 